$\underline{\text { Review Articles }}$

\title{
The Use of Monoclonal Antibodies in the Treatment of Autoimmune Complications of Chronic Lymphocytic Leukemia
}

Luca Laurenti ${ }^{1}$, Barbara Vannata ${ }^{1}$, Idanna Innocenti ${ }^{1}$, Francesco Autore ${ }^{1}$, Francesco Santini ${ }^{1}$, Simona Sica ${ }^{1}$ and Dimitar G Efremov ${ }^{2}$

${ }^{1}$ Department of Hematology, Catholic University of Rome, “A. Gemelli” Hospital, Largo A. Gemelli 8, Rome, Italy

${ }^{2}$ Department of Molecular Hematology, International Centre for Genetic Engineering \& Biotechnology, Campus A. Buzzati-Traverso, Rome, Italy

Correspondence to: Luca Laurenti, MD. Department of Haematology, Catholic University Hospital "A. Gemelli", Rome, Italy. Largo A. Gemelli, 8, 00168 Roma - Italy, Tel: +39-06-35503953, Fax: +39-06-3017319. E-mail: 1.laurenti@rm.unicatt.it

Competing interests: The authors have declared that no competing interests exist.

Published: April 10, 2013

Received: January 15, 2013

Accepted: April 4, 2013

Citation: Mediterr J Hematol Infect Dis 2013, 5(1): e2013027, DOI: 10.4084/MJHID.2013.027

This article is available from: http://www.mjhid.org/article/view/11412

This is an Open Access article distributed under the terms of the Creative Commons Attribution License (http://creativecommons.org/licenses/by/2.0), which permits unrestricted use, distribution, and reproduction in any medium, provided the original work is properly cited.

Abstract. Autoimmune cytopenias are a frequent complication in CLL, occurring in approximately $5-10 \%$ of the patients. The most common manifestation is autoimmune haemolytic anaemia, followed by immune thrombocytopenia and only rarely pure red blood cell aplasia or autoimmune granulocytopenia. Initial treatment is as for the idiopathic autoimmune cytopenias, with most patients responding to conventional corticosteroid therapy. Patients, who do not respond to conventional therapy after 4-6 weeks, should be considered for alternative immunosuppression, monoclonal antibody therapy or splenectomy. While randomized trials demonstrating the benefit of rituximab in CLL-related autoimmune diseases are still lacking, there are considerable data in the literature that provide evidence for its effectiveness.

The monoclonal antibody alemtuzumab also displays considerable activity against both the malignant disease and the autoimmune complication in patients with CLL, although at the expense of greater toxicity. A number of new monoclonal antibodies, such as ofatumumab, GA-101, lumiliximab, TRU-016, epratuzumab, and galiximab, are currently investigated in CLL and their activity in CLL-related autoimmune cytopenias should be evaluated in future studies.

Introduction. Autoimmunity is more common in patients with lymphoproliferative disorders than in patients with myeloproliferative conditions (8\% vs. $1.7 \%$, respectively). ${ }^{1}$ Chronic lymphocytic leukemia (CLL) is characterized by an association with autoimmune phenomena that are stronger than in other chronic lymphoproliferative disorders. ${ }^{2-7}$

Epidemiological data show that the occurrence of autoimmune cytopenia during the clinical history of CLL ranges from $4.3 \%$ to $9.7 \%$. $^{8-12}$ The most common CLL-related immune haematological disturbance is 
autoimmune haemolytic anaemia (AIHA), which occurs in approximately $7 \%$ of the cases. ${ }^{8-10,13}$ An additional proportion of patients (7-14\%) may have a positive direct antiglobulin test (DAT) without clinical evidence of haemolysis. ${ }^{12}$ Immune thrombocytopenic purpura (ITP) and autoimmune granulocytopenia are more rare than AIHA, with an estimated frequency respectively of $1-5 \% .^{8-9,13-14}$ and about $1 \%$. $^{15}$ The incidence of immune disorders involving components of the blood coagulation system, such as acquired haemophilia or acquired von Willebrand disease has not been evaluated.

Regarding the association between CLL and nonhaematological autoimmune disorders, data in the literature report that the proportion of patients with clinically apparent autoimmune disease ranges from $2 \%$ to $12 \%$ while the presence of serological markers of autoimmunity ranges from $8 \%$ to $41 \%$. $16-18$ However, no significant association was observed between CLL and non-haematological autoimmune diseases in case-control studies. ${ }^{4}$ The mechanisms responsible for the development of immune cytopenias in CLL are only partially understood:

1) CLL cells may process red blood cell antigens and act as antigen presenting cells, inducing a T-cell response and the formation of polyclonal antibodies by normal B-cell, thus indirectly provoking autoimmune haemolytic anaemia;

2) CLL cells express inhibitory cytokines which alter tolerance, facilitating the escape of self-reactive cells;

3) rarely CLL cells are effector cells, directly producing a pathological monoclonal autoantibody;

4) CLL cells may be stimulated through their polyreactive BCR which recognizes auto-antigens. ${ }^{4-6}$

An increased risk to develop autoimmune cytopenia has been observed in patients displaying various adverse clinical or biological prognostic features, such as advanced stage, ${ }^{4,9,16,19}$ older age,${ }^{8,12,16}$ high white cell count, ${ }^{8,14,17}$ short lymphocyte doubling time, ${ }^{10,16}$ increased beta-2-microglobulin levels, ${ }^{10,12,17} \mathrm{CD} 38^{10,17}$ and ZAP-70 positivity, ${ }^{9,14}$ unmutated IGVH genes and stereotyped BCRs ${ }^{20-22}$ band poor risk cytogenetics. ${ }^{9,22}$

Recent data of a retrospective series of 585 CLL patients indicated that unmutated IGHV status and/or unfavorable cytogenetic lesions (del17p13 and del11q23) were significantly associated with the risk of developing secondary AIHA $(p<0.0001)$, also suggesting a possible role of specific stereotyped B-cell receptor subsets in a proportion of cases. Stereotyped HCDR3 sequences were identified in $29.6 \%$ of cases and were similarly represented among patients developing or not AIHA; notably, a particular subset (IGHV1-69 and IGHV4-30/IGHD2-2/IGHJ6) was associated with a significantly higher risk of AIHA than the other patients $(\mathrm{p}=0.004)$. Multivariate analysis showed that unmutated IGHV, del17p13 and del11q23, but not this stereotyped subset, were the strongest independent variables associated with AIHA. ${ }^{22}$

To clarify the importance of stage and therapy for the development of autoimmune complications, the GIMEMA Group (Gruppo Italiano Malattie Ematologiche dell'Adulto) conducted a study on 194 CLL cases with autoimmune complications and 434 CLL controls $^{23}$ : AIHA (129 cases) and ITP (35 cases) were typically present in patients multi-treated and/or in advanced stage. Age over the median (> 69 years), stage $\mathrm{C}$, and first and second line therapy were identified as an independent risk factors by multivariate analysis. The majority of patients with AIHA were in stage $\mathrm{C}$, whereas cases of ITP were equally distributed across all 3 Binet stages. Both AIHA and ITP were almost exclusively observed in patients who had received first or second line therapy for CLL. In contrast, non-hematologic autoimmune complications and the presence of serological markers of autoimmunity were mostly observed in patients with early stage CLL (stage A in 17/23 cases), suggesting that different pathogenic mechanisms underlay hematologic and non-hematologic autoimmune phenomena in CLL.

The association between treatment and development of autoimmune cytopenias, particularly AIHA, was described many years ago, ${ }^{24,2,3}$ it was mainly observed in patients treated with the purine analogs fludarabine, cladribine and pentostatin. ${ }^{25-29}$ However, the risk of developing autoimmune cytopenia after exposure to multi-drug regimens containing purine analogues, such as fludarabine plus cyclophosphamide with or without rituximab, is not greater than with other agents. ${ }^{10,12,30,31}$ An intriguing finding emerged from the UK CLL4 trial: the incidence of AIHA was significantly lower in patients treated with fludarabine plus cyclophosphamide $(5 \%)$ than in those allocated to receive chlorambucil (12\%) or fludarabine alone $(11 \%)(\mathrm{p}<0.01)$. That suggests a possible "protective" effect of the addition of cyclophosphamide on the onset of AIHA. ${ }^{12}$ More recent data, coming from the German CLL 8 trial, showed that the rate of AIHA in CLL patients treated with fludarabine and cyclophosphamide, with or without rituximab, was only $1 \%$. $^{31}$

Another crucial question is if the autoimmune cytopenias confer poor prognosis in CLL. In the study of Zent et al., survival of patients with autoimmune cytopenias diagnosed within 1 year of the diagnosis of CLL was similar to survival of patients without CLLrelated cytopenia (median 9.3 vs. 9.7 years, $\mathrm{P}=0.881$ ), suggesting that cytopenia caused by autoimmune disease is not an adverse prognostic factor. In contrast, 
survival of patients with cytopenia due to bone marrow failure was significantly shorter (median 4.4 years, $\mathrm{P}<$ 0.001), demonstrating the need for accurate determination of the etiology of cytopenia in the prognostic classification of patients with CLL. ${ }^{9}$

Treatment. The choice of treatment for autoimmune cytopenias in patients with CLL depends on whether the underlying disease also requires treatment. ${ }^{32}$ Patients with not-progressive CLL and autoimmune cytopenia not requiring treatment for the malignant disease are usually managed in the same manner as patients with a primary autoimmune cytopenia. In contrast, CLL patients with progressive disease requiring treatment for both the underlying disease and the autoimmune cytopenia have more "complex" treatment, requiring systemic chemo-immunotherapy. ${ }^{33}$ Most patients with AIHA are symptomatic and require therapeutic intervention; although most leukemic patients with ITP are asymptomatic and the thrombocytopenia is detected on a routine blood count ${ }^{34}$ they are at higher risk of bleeding than patients with the sole ITP, being frequently older. Thus, it has been recommended to initiate therapy in patients with a platelet count below $30 \times 10^{9} / 1$ also asymptomatic. ${ }^{35}$ Patients with autoimmune cytopenia in the absence of progressive CLL should be treated with conventional therapy, i.e. oral prednisone at a daily dose of 0,5-2 $\mathrm{mg} / \mathrm{kg}$. Prednisone is tapered once a response is observed over several months; pulsed high dose dexamethasone $(40 \mathrm{mg} / \mathrm{d})$ has been also recommended in 4-day pulses every 2 weeks. ${ }^{36}$ Up to $80 \%$ of patients will respond to corticosteroids, but many responders will remain corticosteroid-dependent. ${ }^{8,9,19}$ Patients, who do not respond after 4-6 weeks of therapy, are unlikely to respond. They should be considered for alternative immunosuppression (e.g. cyclosporine, mycophenolate or azathioprine) or, as discussed below, splenectomy, monoclonal antibodies or other biological agents. ${ }^{37,38}$ Intravenous immunoglobulins can be useful when a rapid response is required, e.g. in patients with ITP and significant bleeding, prior to splenectomy or in cases of fulminant haemolysis. However, they will not give a lasting effect as a single agent. The role of splenectomy is better established in ITP than in AIHA. Although in one small series, splenectomy was found to be less effective and associated with greater morbidity in AIHA patients with systemic disease, including CLL, than in patients with idiopathic AIHA. ${ }^{39}$ A more recent study showed a high rate $(67 \%)$ of complete and durable responses in CLL patients treated with laparoscopic splenectomy. ${ }^{40}$

The role of the new thrombopoietin analogues romiplostim and eltrombopag in the treatment of ITP is still controversial. These agents increase platelet production rather than preventing their premature destruction. ${ }^{41}$ The treatment should be taken indefinitely to maintain response, and their long-terms effects are largely unknown: among them, there is the marrow fibrosis. Both drugs have been demonstrated to be efficacious in resistant ITP patients after splenectomy failure and in those patients resistant, who are not surgical candidates. ${ }^{42-44}$ Romiplostim and eltrombopag have been only occasionally reported in CLL-associated ITP treatment. ${ }^{45-48}$ Clearly, the splenectomy in CLL- related ITP seems to have a wider role. Recently, monoclonal antibodies (mAbs) that target normal and malignant B cells, such as rituximab and alemtuzumab, have become part of the standard treatment of CLL and are showing considerable activity against both the malignant disease and the autoimmune complications. (Table 1)

\section{Monoclonal Antibodies.}

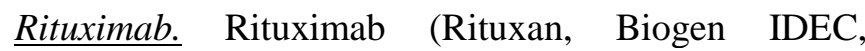
Cambridge, MA, and Mabthera, Hoffman-La Roche, Basel, Switzerland) is one of the first approved chimeric murine/human monoclonal IgG1 antibodies. Rituximab binds to the CD20 antigen, which is expressed on almost all B cells, and eliminates B cells through several mechanisms, including complementdependent cytotoxicity (CDC), antibody dependent cellular cytotoxicity (ADCC), and induction of 'direct cell death' by growth inhibition and non-classic apoptosis. ${ }^{49-51}$ mRituximab is considered to be well tolerated, nevertheless the most notable side effect is

Table 1. Monoclonal antibodies for chronic lymphocytic leukemia

\begin{tabular}{|l|c|c|c|}
\hline Antibody & Antigen & Description & Clinical status \\
\hline Rituximab & CD20 & Chimeric & Approved \\
\hline Alemtuzumab & CD52 & Chimeric & Approved \\
\hline Ofatumumab & CD20 & Humanized & Phase III \\
\hline Lumiliximab & CD23 & Chimaeric & Phase III \\
\hline GA-101 & CD20 & Humanized & Phase I/II \\
\hline TRU-016 & CD37 & Humanized & Phase I/II (NHL) \\
\hline Epratuzumab & CD22 & Humanized & Phase I/II (NHL) \\
\hline Galiximab & CD80 & Chimaeric & \\
\hline
\end{tabular}


the infusion-related reaction, generally mild to moderate in severity. CLL patients with a markedly increased number of circulating lymphocytes present an increased risk of more serious adverse events, including respiratory insufficiency, tumour lysis syndrome and a rapid tumor clearance syndrome. Immunotherapy is frequently associated with grade 3 and 4 neutropenia and leucopenia while other sideeffects, including severe infections, were not increased.

Rituximab represents one of the more active therapies for the treatment of autoimmune complications in CLL that do not respond to initial corticosteroid treatment.(Table 2-3) The first experience with this antibody in the treatment of CLLassociated autoimmune diseases was in two patients with pure red cell aplasia; both responded dramatically to rituximab treatment and became transfusion independent. ${ }^{52}$ Subsequently, Gupta et al treated eight CLL patients with corticosteroid refractory AIHA with a combination of rituximab, cyclophosphamide and dexamethasone (RCD). Cycles were repeated every 4 weeks until the best response. All eight patients achieved a remission of their AIHA and five became Coombs negative. Median duration of response was 13 months. RCD was also effective in achieving a response in patients that subsequently relapsed. ${ }^{53}$

Zaja et al showed that rituximab given at the dose of $375 \mathrm{mg} / \mathrm{m} 2$ per week for 4 weeks is active in various CLL-associated autoimmune diseases that are refractory to standard immunosuppressive therapies. ${ }^{54}$ They treated 7 patients with CLL-associated symptomatic autoimmune diseases, including four patients with warm AIHA, one patient with cold agglutinin disease (CAD), one patient with ITP, and one patient with axonal degenerating neuropathy (ADN). One of the AIHA patients and the patient with $\mathrm{CAD}$ achieved complete normalization of hemoglobin levels and laboratory signs of haemolysis, with response durations of $8+$ and $38+$ months, respectively. In the patient with ITP, complete remission was reached after the first week of treatment and the duration of response was 6 months. The patient with ADN achieved a marked neurological improvement after rituximab therapy, with response duration of 12

Table 2. Rituximab monotherapy for the treatment of autoimmune complications in CLL

\begin{tabular}{|l|l|l|l|}
\hline $\begin{array}{l}\text { Number of patients and type } \\
\text { of autoimmune disorder }\end{array}$ & Treatment protocol & Outcome & Reference \\
\hline 2 PRCA & $375 \mathrm{mg} / \mathrm{m} 2 /$ week for 8 weeks & $\begin{array}{l}\text { Normalized hemoglobin levels and } \\
\text { transfusion independence }\end{array}$ & Ghazal H. et al [52] \\
\hline 4 AIHA, 1 ITP, 1 CAD & $375 \mathrm{mg} / \mathrm{m} 2 /$ week for 4 weeks & $\begin{array}{l}\text { CR in 1 AIHA, 1 CAD and 1 ITP, } \\
\text { mantained for 8+, 38+ and } 6 \text { months } \\
\text { respectively }\end{array}$ & Zaya F. et al [54] \\
\hline 14 AIHA & $375 \mathrm{mg} / \mathrm{m} 2 /$ week for 4 weeks & $\begin{array}{l}\text { CR 22\%, PR 50\%, } \\
8 \text { alive (6 transfusion-free) after a } \\
\text { mean follow-up of 17 months }\end{array}$ & D'Arena G. et al [55] \\
\hline ITP & $375 \mathrm{mg} / \mathrm{m} 2 /$ week for 4 weeks & $\begin{array}{l}\text { Rise in platelet counts in all 3 } \\
\text { patients, maintained for 17+, 6+ and } \\
6 \text { months }\end{array}$ & Hedge UP. Et al [56] \\
\hline $\begin{array}{l}\text { 21 ITP (2 associated with } \\
\text { AIHA) }\end{array}$ & $375 \mathrm{mg} / \mathrm{m} 2 /$ week for 4 weeks & $\begin{array}{l}\text { CR 57\%, PR29\% } \\
\text { (mean duration of response 21 } \\
\text { months) }\end{array}$ & D'Arena G. et al [57] \\
\hline
\end{tabular}

PRCA: pure red cell aplasia; AIHA: autoimmune hemolytic anemia ; ITP: immune thrombocytopenic purpura Immune thrombocytopenic purpura ; CAD: cold agglutinin disease; CR: complete remission; PR: partial remission.

Table 3. Rituximab combination therapy for the treatment of autoimmune complications in CLL

\begin{tabular}{|c|c|c|c|}
\hline $\begin{array}{l}\text { Number of patients and type of } \\
\text { autoimmune disorder }\end{array}$ & Treatment protocol & Outcome & Reference \\
\hline 8 AIHA & $\begin{array}{l}\text { Rituximab }+ \\
\text { cyclophosphamide }+ \\
\text { dexamethasone }(\text { RCD }) \\
\end{array}$ & $\begin{array}{l}\text { Resolution of AIHA in } 8 \text { patients ( } 5 \\
\text { converted into DAT negative). Median } \\
\text { duration of response } 13 \text { months }\end{array}$ & Gupta N. et al [53] \\
\hline $\begin{array}{l}\text { 48 CLL: } 26 \text { AIHA, } 9 \text { ITP, } 8 \text { Evan's } \\
\text { syndrome, } 5 \text { PRCA }\end{array}$ & $\begin{array}{l}\text { Rituximab }+ \\
\text { cyclophosphamide }+ \\
\text { dexamethasone (RCD) } \\
\end{array}$ & $\begin{array}{l}\text { ORR } 89.5 \% \text {, } \\
\text { Median duration of response } 24 \text { months }\end{array}$ & Rossignol J. et al [58] \\
\hline $\begin{array}{l}\text { 21 CLL: } 18 \text { AIHA, } 1 \text { ITP, } 2 \text { Evan's } \\
\text { syndrome }\end{array}$ & $\begin{array}{l}\text { Rituximab }+ \\
\text { cyclophosphamide }+ \\
\text { dexamethasone (RCD) } \\
\end{array}$ & $\begin{array}{l}\text { Resolution of AIHA in all } 20 \text { patients } \\
\text { ( } 10 \text { converted into DAT negative). } \\
\text { Median duration of response } 22 \text { months }\end{array}$ & Kaufman M. et al [60] \\
\hline $\begin{array}{l}20 \text { progressive CLL with AIHA, } \\
\text { PRCA and/or ITP (number of cases } \\
\text { with each autoimmune disorder not } \\
\text { specified) }\end{array}$ & $\begin{array}{l}\text { Rituximab + } \\
\text { cyclophosphamide+ } \\
\text { vincristine + prednisone }(\mathrm{R}- \\
\text { CVP) }\end{array}$ & $\begin{array}{l}\text { Response of autoimmune cytopenia: } 14 \\
\text { CR, } 5 \text { PR. } \\
\text { Response of CLL: } 9 \text { CR, } 8 \text { PR }\end{array}$ & Bowen DA. et al [61] \\
\hline
\end{tabular}

PRCA: pure red cell aplasia; AIHA: autoimmune hemolytic anemia ; ITP: immune thrombocytopenic purpura Immune thrombocytopenic purpura ; CLL: chronic lymphocytic leukaemia; CR: complete remission; PR: partial remission; DAT: direct antiglobulin test; ORR: overall response rate. 
months.

D'Arena et al investigated single agent rituximab in 14 patients with CLL-associated AIHA that failed firstline corticosteroid treatment. ${ }^{55}$ Rituximab was given at a dose of $375 \mathrm{mg} / \mathrm{m}^{2} /$ weekly for 4 weeks. A complete response was observed in $22 \%$ and a partial response in $50 \%$ of the cases. After a mean follow-up of 17 months, 8 patients were still alive, 6 of them transfusion-independent.

Hegde et al showed that rituximab is active in CLL patients with refractory fludarabine-associated ITP. ${ }^{56}$ Three patients who developed ITP while receiving fludarabine and who did not respond to treatment with corticosteroids or intravenous immunoglobulin (IVIG) were treated with weekly rituximab $\left(375 \mathrm{mg} / \mathrm{m}^{2}\right.$ per week for 4 weeks). All patients had rapid and dramatic improvements in their platelet counts, and the response durations were 6 months or greater for all 3 patients.

In a retrospective analysis of 21 patients, D'Arena et al showed that rituximab as a single agent (375 $\mathrm{mg} / \mathrm{m} 2 /$ weekly for four cycles) is effective and welltolerated treatment for CLL-related ITP refractory to corticosteroid therapy. ${ }^{57}$ The overall response rate was $86 \%$ (57\% CR, 29\% PR), with a mean duration of response of 21 months. At a mean follow-up of 28 months, $66 \%$ of patients were still alive, $48 \%$ of them in CR and $14 \%$ in PR.

Recently, immunochemotherapy regimens, such as RCD or rituximab, cyclophosphamide, vincristin and prednisone (R-CVP), have been regaining attention in the treatment of CLL-associated autoimmune diseases, as they can provide both anti-leukemic and antiautoimmune effects in the absence of significant myelosuppression. $^{58-61}$ (Table 3) In the study of Kaufman et al, 18 CLL patients with AIHA, one with ITP and two with both autoimmune diseases were treated with the RCD regimen. All CLL patients with AIHA responded to treatment with a median increase in hemoglobin of $5.2 \mathrm{~g} / \mathrm{dL}$ and a median duration of response of 22 months. Nine relapsed patients responded, as well. Fifty percent of evaluable patients converted to Coombs negative, with a median duration of response of 41 months vs. 10 months for those who did not convert. All 3 patients affected with corticosteroid-refractory ITP also responded to RCD treatment. ${ }^{60}$ Rossignol et al reported the experience of three French university hospitals in the treatment of CLL-associated autoimmune disorders with the RCD protocol. $^{58}$ The study included 48 patients, among which 26 with AIHA, 9 with ITP, 8 with Evan's syndrome and 5 with PRCA, that had relapsed after previous treatment with corticosteroids, splenectomy, rituximab or alemtuzumab. The overall response rate was $89.5 \%$, but relapses occurred in 19 patients (39.6\%). The duration of response (median 24 months) was longer in patients presenting with autoimmune disease early during the course of CLL ( $<3$ years), and in patients with PRCA and AIHA. The time to CLL progression (median of 16 months) was statistically shorter for patients with Evan's syndrome and ITP patients.

Bowen et al treated 20 patients with progressive CLL and autoimmune cytopenia using the R-CVP protocol. A response to treatment with respect to the autoimmune cytopenia was observed in 19 patients (14 $\mathrm{CR}$ and $5 \mathrm{PR}$ ) with a median time to next treatment (TTT) for autoimmune cytopenia of 21.7 months. The progressive CLL responded in 17 patients (9 CR, $8 \mathrm{PR}$ ) with a median TTT of 27.7 months. ${ }^{61}$ Grade 3-4 toxicities were infrequent and included infections $(\mathrm{n}=$ $3)$ and drug-induced pneumonitis $(n=1)$. Altogether, these data suggest that R-CVP is an effective and tolerable regimen for patients with autoimmune cytopenia and progressive CLL.

Alemtuzumab. The monoclonal antibody alemtuzumab (Campath-1H, Genzyme, Cambridge, MA) is a recombinant humanized IgG1 $\mathrm{k}$ mAb targeting the CD52 antigen, which is expressed on normal and malignant human $\mathrm{B}$ and $\mathrm{T}$ lymphocytes, as well as natural killer cells, monocytes and macrophages. ${ }^{62,63}$ The mechanism of action of alemtuzumab includes complement-dependent cytotoxicity, antibodydependent cell-mediated cytotoxicity [64] and possibly direct cytotoxicity, which has been observed in some, ${ }^{65,66}$ but not all studies investigating this issue. ${ }^{67,68}$

Haematological and non-haematological toxicities such as neutropenia, lymphopenia and reactivation of herpes viruses infections, especially cytomegalovirus, are frequent after alemtuzumab therapy. Despite premedication with acetaminophen and diphenhydramine, intravenous administration is associated with adverse infusion reactions in $90 \%$ of patients, often severe; fever has been noted in $85 \%$ of patients frequently coupled with nausea, vomiting and rash. Considering the high risk of adverse infusion events when administered intravenously and the comparable biological activity of subcutaneous alemtuzumab associated to a decreased number of infusion reactions, subcutaneously route of administration has progressively increased.

Immunological recovery after alemtuzumab therapy showed a constant long lasting immune depletion with reduced counts of all lymphoid subsets, especially CD4+ lymphocytes, both in previously untreated and heavily pre-treated B-CLL patients.

Alemtuzumab is active in advanced or refractory CLL $^{69-71}$ and has proven efficacy in patients with highrisk genetic markers such as deletion of chromosome $17 \mathrm{p} 13$ and p53 mutations. ${ }^{72,73}$ The potent antitumor activity of alemtuzumab, in combination with its 
profound immunosuppressive activity, has prompted an investigation of its use in patients with severe and refractory CLL-related AIHA and ITP. However, the experience with Alemtuzumab in the treatment of CLL-related autoimmune disorders is rather limited, and only isolated cases and small series have been reported. (Table 4)

The first case of CLL-related autoimmune disease treated with Alemtuzumab was reported by Rodon et al. $^{74}$ The patient had life-threatening corticosteroidresistant AIHA and PRCA. Following Alemtuzumab treatment he obtained a complete remission of both CLL and anemia, but died of recurrent sepsis and cachexia 10 months after completing the treatment. Another case of CLL and fludarabine-related refractory AIHA that was treated successfully with alemtuzumab was reported by Lundin et al. ${ }^{75}$ The anemia was totally reversed, and hemoglobin level remained at $14 \mathrm{~g} / \mathrm{dL}$ after 15 mo of unmaintained follow-up. In this patient, no infectious complications were noted either during or after alemtuzumab therapy.

Subsequently, Karlsson et al described 5 CLL patients in an advanced stage with severe transfusiondependent AIHA refractory to conventional therapy, including corticosteroids, rituximab and splenectomy, that were treated with subcutaneous (SC) or intravenous (IV) alemtuzumab at a dose of $30 \mathrm{mg}$ three times weekly for a maximum of 12 weeks. ${ }^{76}$ After a median time of 5 weeks (range 4-7), all patients responded with a marked rise in hemoglobin $(\mathrm{Hb})$ concentration: the mean $\mathrm{Hb}$ increased from $7.2 \mathrm{~g} / \mathrm{dl}$ at baseline to $11.9 \mathrm{~g} / \mathrm{dl}$ at the end of treatment. All patients remained stable and without further AIHA episodes after a median follow-up time of 12 months. Treatment was relatively well tolerated, although grade 4 neutropenia occurred in two patients and cytomegalovirus reactivation in one.

The previous findings were further corroborated in our series of three patients with progressive CLL and AIHA that were treated with intravenous low-dose alemtuzumab (10 $\mathrm{mg}$ three times weekly for 10 weeks). ${ }^{77}$ The total dose of alemtuzumab in our series was substantially lower than in the series of Karlsson et al (300 mg vs $880 \mathrm{mg}$, respectively). All three patients responded to alemtuzumab treatment with a $>2 \mathrm{~g} / \mathrm{dl}$ rise in $\mathrm{Hb}$ concentration. The duration of response was similar to the duration of response in the series of Karlsson et al. (10 vs 12 months), but longer treatment was required to achieve response (median 8 vs 5 weeks, respectively). Regarding CLL responses, a partial response was achieved in two and stable disease in one patient. Altogether, these data show that alemtuzumab displays considerable activity against both the malignant disease and the autoimmune complications in patients with CLL.

Ofatumumab and other Monoclonal Antibodies. Ofatumumab (HuMax-CD20; Arzerra, GlaxoSmithKline/Genmab) is a recently approved fully human type I anti-CD20 IgG1k mAb. ${ }^{78,79}$ Ofatumumab induces killing of normal and malignant $\mathrm{B}$ cells via activation of complement and antibody-dependent cellmediated cytotoxicity. ${ }^{79,80}$ Ofatumumab displays activity similar to rituximab with respect to antibodydependent cellular cytotoxicity (ADCC) but has greater complement-dependent cytotoxicity (CDC) and a prolonged and more stable CD20 binding. ${ }^{80}$ It appears to bind a different epitope of CD20 than rituximab. ${ }^{81}$ As expected, the main ofatumumab toxicity observed in nonclinical studies was the severe and prolonged depletion of B lymphocytes both in the peripheral blood and lymphoid organs.

A phase I/II study of ofatumumab at doses of $2000 \mathrm{mg}$ in 33 relapsed/refractory CLL patients demonstrated an overall response rate of $50 \% .^{82}$ Similar efficacy was reported in a larger trial which enrolled 138 patients with CLL refractory to fludarabine and alemtuzumab or CLL with bulky lymphadenopathy: the ORR was $58 \%$ for patients with refractory CLL and $47 \%$ for patients with bulky lymphadenopathy.

Table 4. Alemtuzumab therapy for the treatment of autoimmune complications in CLL

\begin{tabular}{|c|c|c|c|}
\hline $\begin{array}{l}\text { Number of patients and type } \\
\text { of autoimmune disorder }\end{array}$ & Treatment protocol & Outcome & Reference \\
\hline $1 \mathrm{AIHA}+\mathrm{PRCA}$ & $\begin{array}{l}\text { Intravenous: } \\
3 \mathrm{mg} \text { on day } 1,10 \mathrm{mg} \text { on day } 3 \text {, } \\
30 \mathrm{mg} \text { on day } 5 \text {, then } 30 \mathrm{mg} \text { three } \\
\text { times a week }\end{array}$ & $\begin{array}{l}\text { Sustained complete remission of both } \\
\text { CLL and anemia }\end{array}$ & Rodon P. et al [74] \\
\hline 1 AIHA & $\begin{array}{l}\text { Subcutaneous: } \\
30 \mathrm{mg} \text { three times weekly for } 8 \\
\text { weeks }\end{array}$ & $\begin{array}{l}\text { Complete resolution of anemia. } \\
\text { maintained during follow-up of } 15 \\
\text { months }\end{array}$ & Lundin J. Et al [75] \\
\hline 5 AIHA & $\begin{array}{l}\text { Subcutaneous ( } 3 \text { patients) or } \\
\text { intravenous ( } 2 \text { patients): } \\
30 \text { mg three times weekly for a } \\
\text { maximum of } 12 \text { weeks }\end{array}$ & $\begin{array}{l}\text { Complete resolution of anemia in all } \\
\text { patients with no further episodes at a } \\
\text { median follow-up of } 12 \text { months }\end{array}$ & Karlsson C. et al [76] \\
\hline 3 AIHA & $\begin{array}{l}\text { Subcutaneous: } \\
10 \text { mg three times weekly for a } \\
\text { maximum of } 10 \text { weeks }\end{array}$ & $\begin{array}{l}\text { Complete resolution of anemia in all } \\
\text { patients with no further episodes at a } \\
\text { median follow-up of } 10 \text { months }\end{array}$ & Laurenti L. et al [77] \\
\hline
\end{tabular}

PRCA: pure red cell aplasia; AIHA: autoimmune hemolytic anemia ; CLL: chronic lymphocytic leukaemia. 
Ofatumumab is approved in the US for the treatment of patients with CLL who are refractory to fludarabine and alemtuzumab. ${ }^{78}$ However, no data have been reported in the literature regarding the use of ofatumumab in CLL-related autoimmune cytopenias. In addition, several other monoclonal antibodies are currently investigated in CLL, including the anti-CD20

\section{References:}

1. Dührsen U, Augener W, Zwingers T, et al. Spectrum and frequency of autoimmune derangements in lymphoproliferative disorders: analysis of 637 cases and comparison with myeloproliferative diseases. Br J Haematol. 1987; 67: 235-9.

2. Galton DA. The pathogenesis of chronic lymphocytic leukemia. Canadian Medical Association Journal. 1966; 94: 1005-10.

3. Dameshek W. Chronic lymphocytic leukemia - an accumulative disease of immunologically incompetent lymphocytes. Blood. 1967; 29: 566-84.

4. Hamblin TJ, Oscier DG, Young BJ. Autoimmunity in chronic lymphocytic leukaemia. Journal of Clinical Pathology. 1986; 39: 713-716.

5. Kipps TJ, Carson DA. Autoantibodies in chronic lymphocytic leukemia and relateds ystemic autoimmune diseases. Blood. 1993; 81: 2475-2487.

6. Chiorazzi N, Rai KR, Ferrarini M. Chronic lymphocytic leukemia. New England Journal of Medicine. 2005; 352: 804-815.

7. Zent CS, Kay NE. Autoimmune Complications in Chronic Lymphocytic Leukaemia (CLL). Best Practice \& Research Clinical Haematology. 2010; 23: 47-59. PMid:10779422

8. Mauro FR, Foa R, Cerretti R, et al. Autoimmune hemolytic anemia in chronic lymphocytic leukemia: clinical, therapeutic, and prognostic features. Blood. 2000; 95:2786-92. PMid:18373706 PMCid:2675611

9. Zent CS, Ding W, Schwager SM, et al. The prognostic significance of cytopenia in chronic lymphocytic leukaemia/small lymphocytic lymphoma. $\mathrm{Br} \mathrm{J}$ Haematol. 2008; 141: 615-21. http://dx.doi.org/10.1111/j.1365-2141.2008.07086.x PMid:20736453

10. Moreno C, Hodgson K, Ferrer G, et al. Autoimmune cytopenias in chronic lymphocytic leukemia: prevalence, clinical associations, and prognostic significance. Blood. 2010;116 :4771-6. http://dx.doi.org/10.1182/blood-2010-05-286500 PMid:17341265

11. Borthakur G, O'Brien S, Wierda WG, et al. Immune anaemias in patients with chronic lymphocytic leukaemia treated with fludarabine, cyclophosphamide and rituximab-incidence and predictors. $\mathrm{Br} \mathrm{J}$ Haematol. 2007; 136 :800-5. http://dx.doi.org/10.1111/j.1365-2141.2007.06513.x PMid:18055869

12. Dearden C, Wade R, Else M, et al. The prognostic significance of a positive direct antiglobulin test in chronic lymphocytic leukemia: a beneficial effect of the combination of fludarabine and cyclophosphamide on the incidence of hemolytic anemia. Blood. 2008; 111: 1820-6. http://dx.doi.org/10.1182/blood-2007-07101303 PMid: 19074125

13. Dearden C. Disease-specific complications of chronic lymphocytic leukemia. Hematology Am Soc Hematol Educ Program. 2008: 450-456. $\quad$ http://dx.doi.org/10.1182/asheducation-2008.1.450 PMid:17986663

14. Visco C, Ruggeri M, Laura Evangelista M, et al. Impact of immune thrombocytopenia on the clinical course of chronic lymphocytic leukemia. Blood. 2008; 111: 1110-1116. http://dx.doi.org/10.1182/blood-2007-09-111492 PMid:16043218

15. Narra K, Borghaei H, Al-Saleem T, et al. Pure red cell aplasia in Bcell lymphoproliferative disorder treated with rituximab: report of two cases and review of the literature. Leuk Res. 2006; 30: 109-14. http://dx.doi.org/10.1016/j.leukres.2005.05.017 PMid:17145607

16. Barcellini W, Capalbo S, Agostinelli RM, et al. Relationship between autoimmune phenomena and disease stage and therapy in B cell chronic lymphocytic leukemia. Haematologica. 2006; 91 : 1689-92. PMid:17214095

17. Duek A, Shvidel L, Braester A, et al. Clinical and immunologic aspects of B chronic lymphocytic leukemia associated with antibody GA-101, the ant-CD23 antibody Lumiliximab, the anti-CD37 antibody TRU-016, the anti-CD22 antibody Epratuzumab and the anti-CD80 antibody Galiximab. The activity of these antibodies in the treatment of CLL-associated autoimmune cytopenias should also be investigated in future studies.

autoimmune disorders. Isr Med Assoc J. 2006; 8: 828-31 PMid:18838479

18. Vanura K, Le T, Esterbauer H, et al. Autoimmune conditions and chronic infections in chronic lymphocytic leukemia patients at diagnosis are associated with unmutated $\mathrm{IgVH}$ genes. Haematologica. 2008; 93: 1912-6. http://dx.doi.org/10.3324/haematol.12955 PMid:12949883

19. Kyasa MJ, Parrish RS, Schichman SA, et al. Autoimmune cytopenia does not predict poor prognosis in chronic lymphocytic leukemia/small lymphocytic lymphoma. Am J Hematol. 2003; 74 : 1-8. http://dx.doi.org/10.1002/ajh.10369 PMid:8611714

20. Efremov DG, Ivanovski M, Siljanovski N, Pozzato G, Cevreska L, Fais F, Chiorazzi N, Batista FD, Burrone OR. Restricted immunoglobulin $\mathrm{VH}$ region repertoire in chronic lymphocytic leukemia patients with autoimmune hemolytic anemia. Blood 1996;87(9):3869-76. PMid:22322667

21. Visco C, Maura F, Tuana G, Agnelli L, Lionetti M, Fabris S, Novella E, Giaretta I, Reda G, Barcellini W, Baldini L, Neri A, Rodeghiero F, Cortelezzi A. Immune thrombocytopenia in patients with chronic lymphocytic leukemia is associated with stereotyped B-cell receptors. Clin Cancer Res. 2012;18(7):1870-8. http://dx.doi.org/10.1158/1078-0432.CCR-11-3019 PMid:23115077

22. Maura F, Visco C, Falisi E, et al; B-cell receptor configuration and adverse cytogenetics are associated with autoimmune hemolytic anemia in chronic lymphocytic leukemia. Am J Hematol.2013;88:32-36. $\quad$ http://dx.doi.org/10.1002/ajh.23342 PMid: 17145607

23. Barcellini W, Capalbo S, Agostinelli RM, et al; GIMEMA Chronic Lymphocytic Leukemia Group. Relationship between autoimmune phenomena and disease stage and therapy in B-cell chronic lymphocytic leukemia. Haematologica. 2006; 91:1689-92. PMid:5953036 PMCid:1579173

24. Lewis FB, Schwartz RS, Dameshek W. X radiation and alkylating agents as possible -trigger- mechanisms in the autoimmune complications of malignant lymphoproliferative disease. Clin Exp Immunol. 1966;1: 3-11.

25. Bastion Y, Coiffier B, Dumontet C, et al. Severe autoimmune hemolytic anemia in two patients treated with fludarabine for chronic lymphocytic leukemia. Annals of Oncology.1992; 3: 171172.

26. Tosti S, Caruso R, D'Adamo F, et al. Severe autoimmune hemolytic anemia in a patient with chronic lymphocytic leukemia responsive to fludarabine-based treatment. Annals of Hematology. 1992; 65: 238-239.

27. Byrd JC, Hertler AA, Weiss RB, et al. Fatal recurrence of autoimmune hemolytic anemia following pentostatin therapy in a patient with a history of fludarabine-associated hemolytic anemia. Annals of Oncology. 1995; 6: 300-301.

28. Myint H, Copplestone JA, Orchard J, et al. Fludarabine-related autoimmune haemolytic anaemia in patients with chronic lymphocytic leukaemia. British Journal of Haematology. 1995; 91 : 341-344. PMid:9586905

29. Weiss RB, Freiman J, Kweder SL, et al. Hemolytic anemia after fludarabine therapy for chronic lymphocytic leukemia. J Clin Oncol. 1998; 16: 1885-1889. PMid:17341265

30. Borthakur G, O'Brien S, Wierda WG, et al. Immune anaemias in patients with chronic lymphocytic leukaemia treated with fludarabine, cyclophosphamide and rituximab--incidence and

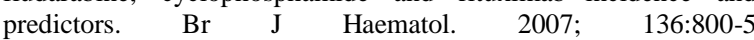
http://dx.doi.org/10.1111/j.1365-2141.2007.06513.x

31. Hallek M, Fischer K, Fingerle-Rowson G, et al. Addition of rituximab to fludarabine and cyclophosphamide in patients with 
chronic lymphocytic leukaemia: a randomised, open-label, phase 3 trial. Lancet. 2010; 376: 1164-1174.

PMid:19850738 PMCid:2941409

32. Gribben JG. How I treat CLL up front. Blood.2012;115:187-97. http://dx.doi.org/10.1182/blood-2009-08-207126 PMid:18216293 PMCid:2972576

33. Hallek M, Cheson BD, Catovsky D, et al; International Workshop on Chronic Lymphocytic Leukemia. Guidelines for the diagnosis and treatment of chronic lymphocytic leukemia: a report from the International Workshop on Chronic Lymphocytic Leukemia updating the National Cancer Institute-Working Group 1996 guidelines. Blood. http://dx.doi.org/10.1182/blood-2007-06-093906

34. Zent CS, Shanafelt T. Management of autoimmune cytopenia complicating chronic lymphocytic leukemia. Leukemia and Lymphoma. 2009; 50: 863-864.

35. Provan D, Stasi R, Newland AC, et al. International consensus report on the investigation and management of primary immune thrombocytopenia. Blood. 2010; 115: 168-186.

36. Mazzucconi MG, Fazi P, Bernasconi S, et al. Therapy with highdose dexamethasone (HD-DXM) in previously untreated patients affected by idiopathic thrombocytopenic purpura: a GIMEMA experience. Blood. 2007; 109: 1401-1407.

37. D’Arena G, Cascavilla N. Chronic lymphocytic leukemiaassociated autoimmunehemolytic anemia. Leukemia and Lymphoma. 2007; 48: 1072-1080.

38. Lechner K, Jager U. How I treat autoimmune hemolytic anemias in adults. Blood. 2010; 116: 1831.

39. Akpek G, McAneny D, Weintraub L. Comparative response to splenectomy in Coombs-positive autoimmune hemolytic anemia with or without associated disease. American Journal of Hematology. 1999; 61: 98-102.

40. Hill J, Walsh RM, McHam S, et al. Laparoscopic splenectomy for autoimmune hemolytic anemia in patients with chronic lymphocytic leukemia: a case series and review of the literature. American Journal of Hematology. 2004; 75:134-138.

41. George JN. Management of immune thrombocytopenia: something old, something new. New England Journal of Medicine. 2010; 363: 1959-1961.

42. Kuter DJ, Rummel M, Boccia R, et al. Romiplostim or standard of care in patients with immune thrombocytopenia. New England Journal of Medicine. 2010; 363: 1889-1899.

43. Kuter DJ, Bussel JB, Lyons RM, et al. Efficacy of romiplostim in patients with chronic immune thrombocytopenic purpura: a doubleblind randomised controlled trial. Lancet. 2008; 371: 395-403.

44. Bussel JB, Provan D, Shamsi T, et al. Effect of eltrombopag on platelet counts and bleeding during treatment of chronic idiopathic thrombocytopenic purpura: a randomised, double-blind, placebocontrolled trial. Lancet. 2009; 373: 641-648.

45. Koehrer S, Keating MJ, Wierda WG. Eltrombopag, a secondgeneration thrombopoietin receptor agonist, for chronic lymphocytic leukemia-associated ITP. Leukemia. 2010; 24: 10961098.

46. D’Arena G, Cascavilla N. Romiplostim for chronic lymphocytic leukemia-associated immune thrombocytopenia. Leukemia and Lymphoma. 2011; 52: 701-704. PMid:16785532

47. Sinisalo M, Sankelo M, Ita"la-Remes M. Thrombopoietin receptor agonists can be used temporarily with patients suffering from refractory chronic lymphocytic leukemia-associated immunologic thrombocytopenia. Leukemia and Lymphoma. 2011; 52: 724-725. PMid:20194898 PMCid:2881503

48. Tadmor T, Polliack A. Expanding the use of thrombopoietin mimetic drugs: what about chronic lymphocytic leukemia? Leukemia and Lymphoma. 2011; 52: 558-559. PMid:15226177

49. Teeling JL, Mackus WJ, Wiegman LJ, et al. The biological activity of human CD20 monoclonal antibodies is linked to unique epitopes on CD20. J Immunol. 2006; 177: 362-71. PMid:11807020

50. Mossner E, Brunker P, Moser S, et al. Increasing the efficacy of CD20 antibody therapy through the engineering of a new type II anti-CD20 antibody with enhanced direct and immune effector cell-mediated B-cell cytotoxicity. Blood. 2010; 115: 4393-4402. http://dx.doi.org/10.1182/blood-2009-06-225979 PMid:12357362

51. Cartron G, Watier H, Golay J, et al. From the bench to the bedside: ways to improve rituximab efficacy. Blood. 2004;104: 2635-2642. http://dx.doi.org/10.1182/blood-2004-03-1110 PMid:23469683 PMCid:3614555
52. Ghazal H. Successful treatment of pure red cell aplasia with rituximab in patients with chronic lymphocytic leukemia. Blood 2002; 99:1092-4. http://dx.doi.org/10.1182/blood.V99.3.1092

53. Gupta N, Kavuru S, Patel D, et al. Rituximab-based chemotherapy for steroid-refractory autoimmune hemolytic anemia of chronic lymphocytic leukemia. Leukemia. 2002; 16: 2092-5. http://dx.doi.org/10.1038/sj.leu.2402676 PMid:20846302

54. Zaja F, Vianelli N, Perotto A, et al. Anti-CD20 therapy for chronic lymphocytic leukemia-associated autoimmune diseases. Leukemia and Lymphoma. 2003; 44: 1951-5. http://dx.doi.org/10.1080/1042819031000119235 PMid:21127498

55. D'Arena G, Laurenti L, Capalbo S, et al. Rituximab therapy for Chronic Lymphocytic leukemia-associated autoimmune hemolytic anemia. American Journal of Hematology. 2006; 81:598-602. PMid:23469683 PMCid:3614555

56. Hegde UP, Wilson WH, White T, et al. Rituximab treatment of refractory fludarabine-associated immune thrombocytopenia in chronic lymphocytic leukemia. Blood. 2002; 15; 100: 2260-2. PMid:23469683 PMCid:3614555

57. D'Arena G, Capalbo S, Laurenti L, et al. Chronic lymphocytic leukemia-associated immune thrombocytopenia treated with rituximab: a retrospective study of 21 patients. Eur J Haematol. 2010; 85: 502-7. $\quad$ http://dx.doi.org/10.1111/j.16000609.2010.01527.x PMid:23469683 PMCid:3614555

58. Rossignol J, Michallet AS, Oberic L, et al. Rituximabcyclophosphamide-dexamethasone combination in the management of autoimmune cytopenias associated with chronic lymphocytic leukemia. Leukemia; 2011: 25: 473-8 http://dx.doi.org/10.1038/leu.2010.278

59. Michallet AS, Rossignol J, Cazin B, et al. Rituximabcyclophosphamide-dexamethasone combination in management of autoimmune cytopenias associated with chronic lymphocytic leukemia. Leukemia and Lymphoma. 2011;52: 1401-3. http://dx.doi.org/10.3109/10428194.2011.591005 PMid:18588450

60. Kaufman M, Limaye SA, Driscoll N, et al. A combination of rituximab, cyclophosphamide and dexamethasone effectively treats immune cytopenias of chronic lymphocytic leukemia. Leukemia and Lymphoma. 2009; 50: 892-899. http://dx.doi.org/10.1080/10428190902887563

61. Bowen DA, Call TG, Shanafelt TD, et al. Treatment of autoimmune cytopenia complicating progressive chronic lymphocytic leukemia/small lymphocytic lymphoma with rituximab, cyclophosphamide, vincristine, and prednisone. Leukemia and Lymphoma. 2010; 51: 620-627. http://dx.doi.org/10.3109/10428191003682767

62. Carson KR, Focosi D, Major EO, et al. Monoclonal antibodyassociated progressive multifocal leucoencephalopathy in patients treated with rituximab, natalizumab, and efalizumab: a Review from the Research on Adverse Drug Events and Reports (RADAR) Project. Lancet Oncol. 2009; 10: 816-824. http://dx.doi.org/10.1016/S1470-2045(09)70161-5

63. Robak T. Alemtuzumab for B-cell chronic lymphocytic leukemia Expert Rev. Anticancer Ther. 2008; 8: 1033-51. http://dx.doi.org/10.1586/14737140.8.7.1033

64. Osterborg A, Foa R, Bezares RF, et al. Management guidelines for the use of alemtuzumab in chronic lymphocytic leukaemia Leukemia. 2009; 23: 1980-1988.

65. Mone AP, Cheney C, Banks AL, et al. Alemtuzumab induces caspase-independent cell death in human chronic lymphocytic leukemia cells through a lipid raft-dependent mechanism. Leukemia. 2006; 20: 272-279.

66. Smolewski P, Szmigielska-Kaplon A, Cebula B, et al. Proapoptotic activity of alemtuzumab alone and in combination with rituximab or purine nucleoside analogues in chronic lymphocytic leukemia cells. Leuk. Lymphoma. 2005; 46: 87-100.

67. Stanglmaier M, Reis S, Hallek M. Rituximab and alemtuzumab induce a nonclassic, caspase-independent apoptotic pathway in Blymphoid cell lines and in chronic lymphocytic leukemia cells. Ann. Hematol. 2004; 83: 634-645. PMid:10354375

68. Zent CS, Chen JB, Kurten RC, et al. Alemtuzumab (CAMPATH $1 \mathrm{H})$ does not kill chronic lymphocytic leukemia cells in serum free medium. Leuk. Res. 2004; 28: 495-507.

69. Zent CS, Secreto CR, Laplant BR, et al. Direct and complement dependent cytotoxicity in CLL cells from patients with high-risk 
early-intermediate stage chronic lymphocytic leukemia (CLL) treated with alemtuzumab and rituximab. Leuk. Res. 2008; 32: $1849-1856$

70. Osterborg A, Dyer MJ, Bunjes D, et al. Phase II multicenter study of human CD52 antibody in previously treated chronic lymphocytic leukemia. European study group of CAMPATH-1H treatment in chronic lymphocytic leukemia. J. Clin. Oncol. 1997; 15:1567-74. PMid:12694169

71. Rai KR, Freter CE, Mercier RJ, et al. Alemtuzumab in previously treated chronic lymphocytic leukemia patients who also had received fludarabine. J. Clin. Oncol. 2002; 20: 3891-7.

72. Keating MJ, Flinn I, Jain V, et al. Therapeutic role of alemtuzumab (Campath-1H) in patients who have failed fludarabine: results of a large international study. Blood. 2002; 99: 3554-61. PMid:17215854

73. Stilgenbauer $\mathrm{S}$, Dohner $\mathrm{H}$. Campath-1H-induced complete remission of chronic lymphocytic leukemia despite p53 gene mutation and resistance to chemotherapy. N. Engl. J. Med. 2002; 347: 452-3. PMid:17443222

74. Rodon P, Breton P, Courouble G. Treatment of pure red cell aplasia and autoimmune haemolytic anaemia in chronic lymphocytic leukaemia with Campath-1H.Eur J Haematol. 2003;70:319-21. 0609.2003.00055.x PMid:20194866

75. Lundin J, Karlsson C, Celsing F. Alemtuzumab therapy for severe autoimmune hemolysis in a patient with B-cell chronic lymphocytic leukemia. Med Oncol. 2006;23:137-9. http://dx.doi.org/10.1385/MO:23:1:137 PMid:20481657
76. Karlsson C, Hansson L, Celsing F, et al. Treatment of severe refractory autoimmune hemolytic anemia in B-cell chronic lymphocytic leukemia with alemtuzumab (humanized CD52 monoclonal antibody).Leukemia. 2007;21:511-4. http://dx.doi.org/10.1038/sj.leu.2404512 PMid:18566448

77. Laurenti L, Tarnani M, Efremov DG, et al. Efficacy and safety of low-dose alemtuzumab as treatment of autoimmune hemolytic anemia in pretreated B-cell chronic lymphocytic leukemia Leukemia. 2007; 21:1819-21 http://dx.doi.org/10.1038/sj.leu.2404703 PMid:15172969

78. Wierda WG, Kipps TJ, Mayer J, et al. Ofatumumab as single-agent CD20 immunotherapy in fludarabine-refractory chronic lymphocytic leukemia. J. Clin. Oncol. 2010; 28: 1749-55 http://dx.doi.org/10.1200/JCO.2009.25.3187 PMid:18535937

79. Sanford M, McCormack PL. Ofatumumab. Drugs. 2010; 70: 1013 1019. http://dx.doi.org/10.2165/11203850-000000000-00000

80. Beum PV, Lindorfer MA, Beurskens F, et al. Complement activation on B lymphocytes opsonized with rituximab or ofatumumab produces substantial changes in membrane structure preceding cell lysis. J. Immunol. 2008; 181: 822-832.

81. Teeling JL, French RR, Cragg MS, et al. Characterization of new human CD20 monoclonal antibodies with potent cytolytic activity against non-Hodgkin lymphomas. Blood. 2004; 104: 1793-1800. http://dx.doi.org/10.1182/blood-2004-01-0039

82. Robak T. Ofatumumab, a human monoclonal antibody for lymphoid malignancies and autoimmune disorders. Curr. Opin $\begin{array}{llll}\text { Mol. } & \text { Ther. 294-309. }\end{array}$ 